\title{
PENERAPAN MODEL PEMBELAJARAN PROBLEM BASED LEARNING (PBL) UNTUK MENINGKATKAN SIKAP PERCAYA DIRI PESERTA DIDIK KELAS III SEKOLAH DASAR
}

\author{
Mutiara Alma Umairoh \\ PPG Prajabatan PGSD Universitas Negeri Yogyakarta, Yogyakarta, Indonesia \\ almamutiara@gmail.com \\ Received: June $06^{\text {th }}, 2021$ \\ Revised: July $21^{\text {st }}, 2021$ \\ Accepted: July $23^{\text {rd }}, 2021$
}

\begin{abstract}
This study aims to increase the self-confident attitude of grade III students of SD Negeri Grindang by applying the PBL learning model. This study is a Classroom Action Research (CAR) using the Kemmis and McTaggart model which includes the empanas of planning, implementation, observation, and reflection. The study included two cycle. Subject and subject data in this study were students of class III SD Negeri Grindang. This research uses collection and teaching techniques through observation, questionnaires and documentation. The data validity used source triangulation and data method triangulation. The data analysis technique used is an interactive analysis model. In pre-cycle, resulting in a percentage of $28,5 \%$ reaches the passing grade. The first cycle resulting in a percentage of $42,85 \%$ reaches the passing grade in classical terms, the second cycle resulting a percentage of $85 \%$ reaches the passing grade in classical terms. The conclusion in this study is the PBL learning model which can increase self-confidence in grade III students of SD Negeri Grindang for the 2020/2021 academic year.
\end{abstract}

Keywords: classroom action research; problem based learning; self-confident

\section{PENDAHULUAN}

Proses pembelajaran yang baik berlangung ketika terdapat interaksi aktif antara guru dan peserta didik yang berlangsung dua arah. Peserta didik terlibat langsung dalam pembelajaran, mengalami langsung apa yang dipelajari, sehingga pembelajaran menjadi bermakna bagi peserta didik. Namun pada kebanyakan guru melaksanakan kegiatan belajar mengajar dengan memindahkan pengetahuan yang dimiliki guru kepada peserta didik, mengisi botol kosong dengan pengetahuan, dimana peserta didik menerima pengetahuan yang pasif, sementara guru memiliki pengetahuan yang akan dihafal oleh peserta didik, serta guru mengkotak-kotakkan peserta didik, dimana guru mengelompokkan peserta 
didik berdasarkan nilai dan memasukkan peserta didik dalam kategori, siapa yang berhak naik kelas, siapa yang tidak, siapa yang bisa lulus dan siapa yang tidak (Lie, 1999; Putra, 2019). Gagasan Paulo Freire (Shodiq, 1999) dengan menambahkan pendidikan semacam inilah yang membuat anak menjadi pasif, tidak berani mengatakan perasaannya, verbalisme, bermental sakit, rendah diri, tidak kritis, dan tidak produktif.

Serin (2018) juga mengemukakan, bahwa ketika guru aktif dalam pembelajaran maka peserta didik akan pasif. Peserta didik hanya mendengarkan apa yang dijelaskan oleh guru tanpa ada aktivitas lain. Tidak terlibatnya peserta didik dalam pembelajaran menyebabkan sikap percaya diri juga tidak terbentuk. Orang yang hidup dengan kepercayan diri yang kuat akan lebih bahagia, oleh karena itu perlunya pembentukan sikap percaya diri sejak dini. Masalah ini juga terjadi di SD N Grindang Kokap, khususnya pada peserta didik kelas III.

Berdasarkan pada hasil refleksi di kelas III SD N Grindang Kokap, guru menerangkan bahwa pembelajaran jarah jauh yang selama ini dilakukan belum menggunakan model-model pembelajaran yang inovatif, guru hanya membagikan tugas melalui Whatsapp Group, kemudian peserta didik mengerjakan tugas-tugas yang diberikan guru. Peserta didik kurang diberi kesempatan untuk mengekspresikan apa yang mereka rasakan, menyampaikan pendapat, mampu bertanya dengan guru, karena pembelajaran dilakukan dengan satu arah pada pemberian tugas. Rendahnya sikap percaya diri yang dialami peserta didik bisa dipengaruhi oleh beberapa faktor, yakni guru belum menggunakan model pembelajaran inovatif yang menekankan pada pembentukan sikap, kemudian dalam pembelajaran juga guru masih menjadi satu-satunya sumber belajar sehingga peserta didik cenderung pasif dan sukar untuk mengekspresikan apa yang mereka rasakan, sukar bertanya maupun berpendapat.

Berdasarkan pada hasil refleksi diatas, guru harus memilih pendekatan, model, metode, ataupun media yang relevan dengan pokok bahasan yang dipaparkan sehingga dapat dijadikan solusi dari permasalahan yang ada. Salah satu model yang dapat meningkatkan sikap percaya diri yaitu model PBL. 
Penerapan model PBL ini ialah peserta didik akan bekerjasama dalam kelompok kecil untuk menyelesaikan permasalahan yang ada (Hmelo and Silver, 2004). Penggunaan model PBL tersebut dapat memicu peserta didik untuk berani berpendapat, bertanya, mengeluarkan ide-ide sehingga sikap percaya diri harapkan dapat terbentuk dalam penyelesian suatu masalah. Percaya diri adalah keyakinan seseorang terhadap segala aspek yang dimilikinya yang membuatya merasa mampu dapat mencapai suatu tujuan dan melakukanya (Adywibowo, 2010; Hakim, 2002). Penerapan model pembelajaran model Problem Based Learning (PBL) untuk meningkatkan sikap Percaya diri pernah dibuktikan dalam penelitian Eko (2018) yakni meningkatnya sikap percaya diri dan hasil belajar dengan pengunaan model Problem Based Learning ( $\mathrm{PBL}$ ), dengan presentase ketuntasan akhir yakni $85 \%$. Perbedaan yang mendasar antara penelitian ini dengan penelitian Eko yaitu pada variabel bebas, penelitian ini hanya berfokus pada sikap percaya diri saja, sedangkan pada penelitian sebelumnya berfokus pada sikap percaya diri dan hasil belajar. Oleh karena itu peneliti menggunakan model PBL untuk mengatasi permasalahan yang sama yakni percaya diri namun pada materi, dan jenjang kelas yang berbeda. Bepijak pada permasalahan yang ada, peneliti tertarik untuk melakukan perbaikan pada sikap percaya diri melaluii PTK yang berjudul "Penerapan Problem Based Learning (PLB) Untuk Meningkatkan Sikap Percaya Diri Pada Peserta Didik Kelas III SD N Grindang Kokap Tahun Ajaran 2020/2021".

\section{METODE PENELITIAN}

Penelitian yang digunakan penulis adalah Penelitian Tindakan Kelas (PTK) (lihat Komara, Putra, \& Hermita, 2020). PTK ini dilakukan pada kelas III SD Negeri Grindang tahun ajaran 2020/2021 yang beralamat di dusun Grindang, Hargomulyo, Kepanewon Kokap, Kabupaten Kulon Progo. Waktu penelitian ini dari bulan Januari 2021 sampai dengan bulan Mei 2021. Subjek penelitian ini yaitu peserta didik kelas III SD Negeri Grindang, dengan peserta didik perempuan berjumlah 3 orang, dan peserta didi laki-laki berjumlah 4 orang. 
PTK ini dilakukan selama dua siklus, dengan setiap siklus terdiri dari dua pertemuan. Setiap siklus terdiri dari empat tahapan yaitu perencanaan, pelaksanaan, observasi, dan terakhir refleksi. Sumber data dalam penelitian ini adalah peserta didik kelas III SD Negeri Grindang, dan dokumen. Penelitian ini menggunakan teknik pengumpulan data meliputi observasi, angket, dan dokumentasi. Penelitian ini menggunakan validitas data triangulasi sumber dan triangulasi metode pengumpulan data. Teknik analisis data yang digunakan dalam penelitian ini adalah teknik model analisis interaktif. Penelitian dikatakan berhasil apabila $80 \%$ peserta didik tuntas dengan kategori baik atau sangat baik. Penelitian ini menggunakan penilaian yang berpijak pada penelitian kurikulum 2013. Kurniasih \& Sani (2016) menjelaskan bahwa skala nilai dalam kurikulum 2013 pada Tabel 1 berikut ini.

Tabel 1. Kategorisasi dan konverensi sikap percaya diri

\begin{tabular}{|c|c|}
\hline $\begin{array}{c}\text { Sangat } \\
\text { baik }\end{array}$ & $\begin{array}{c}=\text { apabila memperoleh skor, } \\
3,33<\text { skor } \leq 4,00\end{array}$ \\
\hline Baik & $\begin{array}{c}=\text { apabila memperoleh skor, } \\
2,33<\text { skor } \leq 3,33\end{array}$ \\
\hline Cukup & $\begin{array}{c}=\text { apabila memperoleh skor, } \\
1,33<\text { skor } \leq 2,33\end{array}$ \\
\hline Kurang & $\begin{array}{c}=\text { apabila memperoleh skor, } \\
\text { skor } \leq 1,33\end{array}$ \\
\hline
\end{tabular}

Pada penelitian ini ketuntasan peserta didik dilihat dari hasil observasi dan angket percaya diri. Peserta didik dikatakan tuntas jika memiliki sikap percaya diri dalam kategori baik atau sangat baik.

\section{HASIL PENELITIAN}

Indikator sikap percaya diri yang digunakan dalam PTK ini yakni berani berpendapat, berani bertanya dan menjawab pertanyaan, serta berani presentasi. Indikator tersebut kemudian dijabarkan menjadi beberapa deskriptor. Berdasarkan hasil observasi awal pratindakan terhadap peserta didik kelas III SD Negeri Grindang, dan hasil observasi awal pratindakan menunjukaan bahwa sikap 
TUNJUK AJAR: JURNAL PENELITIAN ILMU PENDIDIKAN

Volume 4, Nomor 2, 2021

P-ISSN: 2615-062X

E-ISSN: 2622-3554

http://dx.doi.org/10.31258/ita.v4i2.140-150

percaya diri yang dimiliki peserta didik masih rendah. Berdasarkan hasil pratindakan hanya terdapat 2 orang peserta didik (28,5\%) yang mendapatkan kategori baik. Tabel 2 ini merupakan hasil pratindakan sikap percaya diri.

Tabel 2. Hasil Pratindakan Sikap Percaya Diri

\begin{tabular}{|l|l|c|c|}
\hline \multicolumn{1}{|c|}{ Kategori } & \multicolumn{1}{c|}{ Skor } & Frekuensi & Presentase (\%) \\
\hline Kurang & skor $\leq 1,33$ & 1 & 14,28 \\
\hline Cukup & $1,33<$ skor $\leq 2,33$ & 4 & 57,14 \\
\hline Baik & $2,33<$ skor $\leq 3,33$ & 2 & 28,5 \\
\hline Sangat Baik & $3,33<$ skor $\leq 4,00$ & 0 & 0 \\
\hline Total & & 7 & 100 \\
\hline
\end{tabular}

Merujuk pada Tabel 2 hasil observasi awal pratindakan sikap percaya diri ini hanya 2 orang perserta didik yang mencapai kategori baik atau sekitar 28,5\%. Masih terdapat 4 peserta didik atau sekitar 57,14\% yang masuk kategori cukup, dan 1 peserta didik atau sekitar 14,28\% yang masuk dalam ketegori kurang. Berdasarkan hasil pratindakan tersebut, kemudian dilanjutkan pada siklus I dengan menerapkan model pembelajaran Problem Based Learning (PBL) untuk meningkatkan sikap percaya diri, hasilnya adalah sebagai berikut :

Tabel 3. Hasil Ketuntasan Klasikal Sikap Percaya Diri Siklus I

\begin{tabular}{|l|l|c|c|}
\hline \multicolumn{1}{|c|}{ Kategori } & \multicolumn{1}{c|}{ Skor } & Frekuensi & Presentase (\%) \\
\hline Kurang & skor $\leq 1,33$ & 0 & 0 \\
\hline Cukup & $1,33<$ skor $\leq 2,33$ & 4 & 57,12 \\
\hline Baik & $2,33<$ skor $\leq 3,33$ & 3 & 42,85 \\
\hline Sangat Baik & $3,33<$ skor $\leq 4,00$ & 0 & 0 \\
\hline Total & & 7 & 100 \\
\hline
\end{tabular}


Merujuk pada Tabel 3 menunjukkan sebanyak 57,12\% (4 anak) belum tuntas dengan kategori sikap percaya diri cukup. Peserta didik yang mencapai kategori baik terdapat 3 orang atau sekitar $(42,85 \%)$. Hal tersebut belum mencapai kinerja penelitian yaitu $80 \%$, maka akan dilanjutkan pada siklus II, untuk memperbaiki permasalahan yang terdapat dalam siklus I, sesuai hasil refleksi dalam siklus I. Hasil ketuntasan klasikal sikap percaya diri siklus II, dapat dilihat pada Tabel 4 di bawah ini.

Tabel 4. Hasil Ketuntasan Klasikal Sikap Percaya Diri Siklus II

\begin{tabular}{|l|l|c|c|}
\hline \multicolumn{1}{|c|}{ Kategori } & \multicolumn{1}{c|}{ Skor } & Frekuensi & Presentase (\%) \\
\hline Kurang & skor $\leq 1,33$ & 0 & 0 \\
\hline Cukup & $1,33<$ skor $\leq 2,33$ & 1 & 14,28 \\
\hline Baik & $2,33<$ skor $\leq 3,33$ & 6 & 85,71 \\
\hline Sangat Baik & $3,33<$ skor $\leq 4,00$ & 0 & 0 \\
\hline Total & skor $\leq 1,33$ & 0 & 0 \\
\hline
\end{tabular}

Berdasarkan Tabel 4 menunjukkan terdapat 1 anak (14,28\%) yang masih masuk kategori cukup, serta peserta didik yang sudah mencapai kategori baik sebanyak 6 orang atau sekitar $(85,71 \%)$. Ketuntasan klasikal pada siklus II ini yaitu $85,71 \%$, dan sudah mencapai indikator kinerja penelitian $80 \%$ peserta didik yang mencapai kategori baik atau sangat baik, oleh karena itu penelitian di hentikan pada siklus II. Perbandingan perolehan sikap percaya diri peserta didik kelas III SD Negeri Grindang dari pratindakan sampai siklus II dapat dilihat pada Tabel 5 di bawah ini : 
Tabel 5. Perbandingan Sikap Percaya Diri Antar Siklus

\begin{tabular}{|l|l|c|c|c|}
\hline \multirow{2}{*}{ No } & \multirow{2}{*}{ Kategori } & \multicolumn{3}{|c|}{ Kondisi } \\
\cline { 3 - 5 } & & Pratindakan & Siklus I & Siklus II \\
\hline 1 & Kurang & 1 & 0 & 0 \\
\hline 2 & Cukup & 4 & 4 & 1 \\
\hline 3 & Baik & 2 & 3 & 6 \\
\hline 4 & Sangat Baik & 0 & 0 & 0 \\
\hline
\end{tabular}

Tabel 5 diatas menunjukkan perbandingan perolehan sikap percaya diri mulai dari pratindakan, siklus I, sampai siklus II. Kondisi pratindakan hanya terdapat 2 peserta didik yang masuk kategori baik. Oleh karena itu, diterapkan model pembelajaran PBL pada Tema 7 Perkembangan Teknologi agar peserta didik dapat mengalami peningkatan sesuai indikator kinerja penelitian yakni $80 \%$ peserta didik masuk dalam kategori baik atau sangat baik. Perolehan pada siklus I untuk kategori baik mengalami peningkatan dari 2 menjadi 3 peserta didik. Perolehan pada siklus II untuk kategori baik mengalami peningkatan dari 3 menjadi 6 peserta didik. Ketuntasan klasikal pada siklus II yakni 85,71\%, maka indikator kinerja penelitian sudah tercapai, dan penelitian di hentikan pada siklus II.

Penelitian yang relevan dilakukan oleh Eko (2018) yakni meningkatnya sikap percaya diri dan hasil belajar dengan pengunaan model Problem Based Learning (PBL). Hasil data percaya diri pada siklus I sebesar $47 \%$ meningkat di siklus II menjadi $68 \%$, dan meningkat di siklus III menjadi $85 \%$. Penelitian tersebut sejalan dengan penelitian ini yakni sikap percaya diri peserta didik kelas III SD Negeri Grindang tahun ajaran 2020/2021 mengalami peningkatan dari sebelum dan sesudah diterapkanya model pembelajaran Problem Based Learning (PBL). 
Hal tersebut dapat dilihat berdasarkan hasil angket dan observasi yang mengalami peningkatan.

\section{PEMBAHASAN PENELTIAN}

Penerapan model pembelajaran Problem Based Learning (PBL) dapat meningkatkan sikap percaya diri peserta didik kelas 3 SD Negeri Grindang Tahun Ajaran 2020/2021. Berdasarkan pada hasil ketuntasan klasikal sikap percaya diri dari pratindakan, siklus I, sampai siklus II. Indikator penelitian yang telah ditetapkan yaitu $80 \%$ peserta didik mampu memenuhi sikap percaya diri baik atau sangat baik. Berdasarkan pada hasil observasi awal peserta didik kelas 3 mengenai rendahnya sikap percaya diri, ditandai dengan peserta didik kurang partisipasinya dalam pembelajaran, kemudian peserta didik masih malu-malu dan tidak berani menatap kamera saat membuat video untuk menyampaikan atau mempresentasikan tugas.

Berdasarkan pada data pratindakan, siklus I, dan siklus II mengalami peningkatan siap percaya diri pada tiap siklusnya. Peningkatan sikap percaya diri pada peserta didik kelas 3 SD Negeri Grindang dapat terlihat dari sebelum dilakukan tindakan sampai setelah dilakukan tindakan sampai siklus II. Sikap percaya diri peserta didik kelas 3 SD Negeri Grindang yang awalnya kurang partisipasi dalam pembelajaran, dan masih malu-malu saat menyampaikan atau mempresentasikan tugas. Sikap percaya diri peserta didik kelas 3 SD Negeri Grindang mengalami peningkatan ditandai dengan peserta didik mulai aktif mengikuti pembelajaran menggunakan WA, berani menyampaikan pendapat, berani bertanya dan menjawab pertanyaan, serta berani saat presentasi atau menyampaikan hasil tugas.

Proses penelitian sikap percaya diri pada peserta didik kelas 3 SD Negeri Grindang dibantu oleh observer yang membantu untuk mengobservasi peserta didik saat menjalankan proses pembelajaran menggunakan model pembelajaran Problem Based Learning (PBL). Sikap percaya diri peserta didik kelas 3 SD Negeri Grindang meningkat berdasarkan 3 indikator yang masuk pada kategori 
baik atau sangat baik. Indikator sikap percaya diri yang pertama ialah berani perpendapat dari awal peserta didik yang masuk kategori baik ada 4 orang, serta sangat baik ada 3 orang meningkat menjadi peserta didik yang masuk kategori baik ada 3 orang, dan masuk kategori sangat baik yakni 4 orang. Sedangkan pada indikator berani bertanya dan menjawab pertanyaan, peserta didik yang masuk kategori kurang terdapat 1 orang, dan 6 peserta didik masuk kategori baik, meningkat menjadi 1 peserta didik masuk kategori cukup, dan 6 peserta didik masuk kategori baik. Indikator yang terakhir yakni berani berpendapat, peserta didik yang masuk kategori kurang ada 2 peserta didik, dan 5 peserta didik masuk kategori baik, kemudian meningkat menjadi hanya 1 peserta didik yang masuk kategori kurang, 4 peserta didik masuk kategori baik, dan 2 peserta didik masuk kategori sangat baik.

Dampak positif yang ditimbulkan setelah dilakukanya penelitian yakni peserta didik menjadi semakin aktif dalam pembelajaran, berani berpendapat, berani bertanya dan menjawab pertanyaan, serta berani presentasi hasil tugas. Penelitian ini berlangsung sampai siklus II. Hasil penelitian tersebut bahwa model pembelajaran Problem Based Learning (PBL) dapat meningkatkan sikap percaya diri pada peserta didik kelas 3 SD Negeri Grindang Tahun Ajaran 2020/2021. Hal tersebut dibuktikan pada saat kondisi awal ketuntasan klasikal hanya mencapai 28,5\% atau 2 dari 7 peserta didik masuk kategori baik. Pada siklus I ketuntasan klasikal mencapai $43 \%$ atau 3 dari 7 peserta didik masuk kategori baik, sedangkan pada siklus II ketuntasan klasikal mencapai $86 \%$ atau sekitar 6 dari 7 peserta didik masuk kategori baik atau sangat baik. Indikator kinerja pada penelitian ini yakni $80 \%$ dan telah tercapai pada siklus II ini, maka penelitian berhenti pada siklus II. Oleh karena itu model pembelajaran Problem Based Learning (PBL) dapat menjadi salah satu cara alternatif untuk meningkatkan sikap percaya diri peserta didik. Sejalan dengan gagasan (Huda \& Umam, 2018), bahwa melalui model PBL peserta didik dapat berkembang secara utuh, baik kognitif, afektif, maupun psikomotoriknya secara otomatis melalui masalah yang dihadapi. 


\section{SIMPULAN}

Berpijak pada data di atas, penelitian sebanyak dua siklus pada Tema 7 Perkembangan Teknologi dengan menerapkan model PBL pada peserta didik kelas III SD N Grindang tahun ajaran 2020/2021 terhadap sikap percaya diri dapat disimpulkan mengalami peningkatan. Peningkatan tersebut dapat diketahui dari perbandingan perolehan pratindakan dimana ketuntasan diperoleh oleh 2 anak $(28,5 \%)$. Selanjutnya dilakukan tindakan pada siklus I dengan peningkatan ketuntasan dari 2 anak menjadi 3 anak (42,85\%). Siklus II menjelaskan adanya peningkatan ketuntasan dari 3 anak menjadi 6 anak (85,71\%). Hasil penelitian ini memberikan implikasi teoritis yakni menambah pengetahuan pembaca sehingga dapat dijadikan referensi untuk riset lebih lanjut. Penelitian ini juga memberikan implikasi praktis bagi proses pembelajaran berupa peningkatan sikap percaya diri melalui model Problem Based Learning (PBL). Model pembelajaran tersebut efektif dan efisien untuk mengatasi permasalahan sejenis, bahkan terhadap permasalahan lain.

\section{DAFTAR PUSTAKA}

Adywibowo, I. P. (2010). Memperkuat Kepercayaan Diri Anak Melalui Percakapan Referensial. Jurnal Pendidikan Penabur, 15, 37-49.

Anita, L. (1999). Cooperative Learning: Mempraktikkan Cooperative Learning di Ruang-Ruang Kelas. Jakarta: Grasindo.

Aryanto, E. (2018). "Penerapan Model Pembelajaran Problem Based Learning (PBL) untuk Meningkatkan Sikap Percaya diri dan Hasil Belajar Siswa pada Tema I Organ Gerak Hewan dan Manusia (Penelitian Tindakan Kelas, pada Siswa Kelas V C Semester I SDN 114 Bojongkoneng Cibeunying Kota Bandung Tahun Ajaran 2018/2019" Universitas Pasundan Hakim, T. (2002). Mengatasi Rasa Tidak Percaya Diri. Puspa Swara.

Hmelo, C., \& Silver. (2004). Problem-Based Learning: What and How Do Students Learn? Educationals Psychology Review, 16(3).

Huda, M. J., \& Umam, N. K. (2018). KEEFEKTIFAN MODEL PROBLEM BASED LEARNING DALAM MENINGKATKAN HASIL BELAJAR MATEMATIKA KELAS V SDIT AZ-ZAHRA DEMAK. Jurnal Tunjuk Ajar, 1(2), 88-93. 
Komara, F. H. T., Putra, Z. H., \& Hermita, N. (2020). Penerapan model pembelajaran kooperatif tipe picture and picture untuk meningkatkan hasil belajar matematika siswa kelas IVB SDN 136 Pekanbaru. Tunjuk Ajar: Jurnal Penelitian IImu Pendidikan, 3(2), 146 - 162. http://dx.doi.org/10.31258/jta.v3i2.146-162

Kurniasih, I., \& Sani, B. (2016). Revisi Kurikulum 2013. Implementasi Konsep dan Penerapan. Kata Pena.

Putra, Z. H. (2019). Elementary teachers' knowledge on fraction multiplication: An anthropological theory of the didactic approach. Journal of Teaching and Learning in Elementary Education,2(1), 47-52. http://dx.doi.org/10.33578/jtlee.v2i1.6964

Serin, H. (2018). A Comparasion of Teacher-acaentered and Student-Centered Approached in Educational Settings. International Journal of Social Sciences \& Educational Studies, 5(1). 